\title{
HISTOPATOLOGI GINJAL MENCIT (Mus musculus L.) JANTAN AKIBAT RADIASI CAHAYA LAMPU MERKURI
}

\section{HISTOPATHOLOGY OF RENAL MALE MICE (Mus musculus L.) AFFECTED BY RADIATION LIGHTNING OF MERCURY LAMP}

\author{
Rahmat Hidayat ${ }^{1}$, Hendri Busman ${ }^{1}$, Nuning Nurcahyani ${ }^{1}$ \\ 1 Jurusan Biologi FMIPA Universitas Lampung, Bandar Lampung \\ e-mail : rabel89@rocketmail.com \\ Jurusan Biologi FMIPA Universitas Lampung \\ JI. Soemantri Brojonegoro No.1, Bandar Lampung, Lampung, Indonesia, 35145
}

\begin{abstract}
ABSTRAK
Lampu merkuri menjadi salah satu pilihan karena memiliki umur nyala yang panjang, hingga 24.000 jam. Radiasi yang dipancarkan lampu ini bukan hanya dalam bentuk fisik tampak, tetapi juga berupa gelombang elektromagnetik dan akan berinterakasi dengan semua materi yang memiliki potensial listrik. Untuk melihat pengaruh radiasi cahaya lampu merkuri terhadap struktur tubulus ginjal mencit (Mus musculus L.) jantan maka telah dilaksanakan penelitian di laboratorium Zoologi Jurusan Biologi FMIPA Universitas Lampung. Pembuatan preparat histologi ginjal dilaksanakan di Laboratorium Patologi Balai Penyidikan dan Pengujian Veteriner (BPPV) Regional III Bandar Lampung. Penelitian ini dilaksanakan dari bulan Oktober sampai November 2012. Kerusakan tubulus ginjal yang ditemukan dalam pemajanan 12 dan 16 jam/hari selama 21 hari berupa perdarahan intertubular, piknosis, karioreksis, kariolisis, kongesti, dan nekrosis. Perdarahan intertubulus hanya ditemukan pada perlakuan $4 \mathrm{jam} / \mathrm{hari}$, sedangkan pada perlakuan 8 jam/hari ditemukan perdarahan intertubulus, piknosis, dan karioreksis.
\end{abstract}

Kata kunci : Radiasi, lampu merkuri, tubulus ginjal, mencit (Mus musculus L.).

\begin{abstract}
Mercury lamp is widely used since it has long-lifes, up to 24,000 hours. Radiation generated by the lamp is not only in the form of physical, but also results electromagnetic waves which will interact with all materials that has electrical potential. The purpose of the research was to observe the effects of merkuri lamp radiation on the structure of renal tubules of male mice (Mus musculus L.). The research was conducted in the laboratory of Zoology Department of University of Lampung, for rearing and treatment of test animals, while slides production of ren anatomy conducted in Pathology Laboratory Regional III Bandar Lampung from October to November 2012. Renal tubular damage such as intertubulus haemorhage, pyknosis, karyorrhexsis, karyolysis, congestion, and necrosis were found in 12 and 16 hours/day of exposure for 21 days. Meanwhile treatment of 4 hours/day only caused intertubular haemorhage, whereas treatment of 8 hours/day was caused intertubulus haemorhage, pyknosis, and karyorrhexsis.
\end{abstract}

Keyword : Radiation, renal tubulus, mice (Mus musculus L.)

\section{PENDAHULUAN}

Kehidupan manusia zaman sekarang hampir tidak dapat dipisahkan dari teknologi dalam bentuk berbagai peralatan berhubungan dengan fisiologi manusia antara lain: microwave, komputer, telepon, televisi, alat-alat kedokteran, mobil, lampu, dan benda-benda elektronik lain yang memancarkan radiasi gelombang elektromagnetik maupun elektrostatik, beberapa bahkan dapat memodifikasi gen (Lim, 2008).
Lampu merkuri blended merupakan kombinasi lampu pijar dengan lampu merkuri fluoresen. Lampu pijar mengahasilkan warna kekuningan sedangkan yang dihasilkan lampu merkuri fluoresen cahayanya dominan ultra violet. Filamen tungsten dihubungkan seri dengan salah satu elektroda utama yang berfungsi untuk membatasi arus saat lampu bekerja dengan demikian lampu merkuri blended ini tidak memerlukan balas lagi di luar filamen tungsten. Di samping sebagai pembatas arus, juga berfungsi untuk menghasilkan cahaya dominan infra merah. Filamen ini akan menyerap seba- 
gian panas yang dihasilkan lampu, sehingga berakibat mengurangi efikasi lampu dan rentang usia pemakaian. Oleh karena itu efikasinya antara 12 sampai 25 lumen/watt, sedangkan rentang usianya sampai dengan 6.000 jam menyala.

Penggunaan lampu ini merupakan alternatif pengganti lampu pijar untuk penerangan industri dan komersil dengan efikasi dan rentang usia pemakaian yang lebih tinggi, sehingga biaya pemasangan awal lebih rendah (Siswono, 2008).

Mencit merupakan hewan mamalia yang mempunyai peranan penting bagi manusia untuk tujuan ilmiah karena memiliki daya adaptasi yang baik dan memiliki beberapa keunggulan antara lain penanganan dan pemeliharaan yang mudah, sehat dan bersih, kemampuan reproduksi tinggi dengan masa kebuntingan singkat, serta memiliki karakteristik produksi dan reproduksi yang mirip dengan mamalia lainnya (Malole dan Pramono, 1989).

Secara anatomis ginjal terbagi menjadi 2 bagian yaitu korteks dan medulla. Di dalam korteks terdapat berjuta-juta nefron. Sedangkan di dalam medulla banyak terdapat duktuli ginjal. Nefron adalah unit fungsional terkecil dari ginjal yang terdiri atas, tubulus kontortus proksimalis, kor-puskulus renal, tubulus kontortus distalis, segmen tipis, dan tebal ansa Henle, serta tubulus kolagens. Darah yang membawa sisa-sisa hasil metabolisme tubuh difiltrasi di dalam glomeruli kemudian di tubuli ginjal, beberapa zat yang masih di-perlukan tubuh mengalami reabsorbsi dan zat-zat hasil sisa metabolisme me-ngalami sekresi bersama air membentuk urine. Setiap hari tidak kurang dari 180 liter cairan tubuh difiltrasi di glomerulus dan menghasilkan urin 1-2 liter. Urin yang terbentuk di dalam nefron disalurkan melalui piramida ke sistem pelvikalis ginjal untuk kemudian disalurkan ke dalam ureter (Purnomo, 2009).

\section{BAHAN dan METODE}

Pemeliharaan dan perlakuan hewan uji, dilaksanakan di Laboratorium Zoologi Jurusan Biologi FMIPA Universitas Lampung sedangkan pembuatan preparat histopatologi ginjal dilaksanakan di Laboratorium Patologi Balai Penyidikan dan Pengujian Veteriner (BPPV) Regional III Bandar Lampung dari bulan Oktober sampai November 2012.

Obyek penelitian ini berupa dua puluh ekor mencit (Mus musculus L) jantan dewasa dengan berat rata-rata 30-35 gram berumur dela- pan minggu yang diperoleh dari Bagian Breeding BPPV Regional III Bandar Lampung.

Sebelum percobaan dimulai, terlebih dahulu dilakukan aklimatisasi mencit selama 7 hari. Baik kelompok kontrol dan kelompok perlakuan dtempatkan dalam ruangan percobaan yang sama. Terhadap kelompok percobaan dilakukan pencahayaan dengan lampu merkuri yang diletakkan pada jarak 1,5 meter dari mencit.

Perlakuannya adalah pemajanan dengan lampu merkuri berdaya 160 watt atau sama dengan 1950 lux yang terdiri dari 5 perlakuan yaitu 0 jam/hari, 4 jam/hari, 8 jam/hari, 12 jam/hari, dan 16 jam/hari selama 21 hari.

Setelah masa perlakuan berakhir, mencitmencit ini kemudian dikorbankan dengan cara dislokasi leher. Hewan yang telah dinekropsi diambil ginjalnya, kemudian diawetkan di dalam larutan formalin $10 \%$. Setelah larutan berpenetrasi sempurna ke dalam organ, langkah selanjutnya adalah grossing (memilih bagian dari organ yang akan dijadikan sediaan histopatologi) kurang lebih dengan pemotongan setebal 0,5 cm (Samkhan dan Sri, 2006).

Data berupa deskripsi gambaran histologis tubulus ginjal mencit jantan yang dipajan cahaya lampu merkuri dengan waktu yang berbeda.

\section{HASIL dan PEMBAHASAN}

Pengamatan histopatologi terhadap ginjal mencit jantan akibat pemajanan radiasi cahaya lampu merkuri dengan perlakuan 0 jam/hari (kontrol), 4 jam/hari, 8 jam/hari, 12 jam/hari dan 16 jam/hari selama 21 hari, menunjukkan adanya beberapa kerusakan struktur histopatologi tubulus ginjal kecuali pada kelompok kontrol yang dapat dikatakan normal. Struktur histopatologi kelompok kontrol tidak menunjukkan adanya kerusakan pada tubulus ginjal seperti kongesti, pendarahan intertubular, piknosis, karioreksis, kariolisis, dan nekrosis. Pada kelompok 1 yaitu mencit dengan lama pemajanan 4 jam/hari selama 21 hari ditemukan adanya pendarahan intertubular yang ditandai dengan pendarahan berlebih di ruang antar tubulus. Pada pemajanan 8 jam/hari juga ditemukan pendarahan intra tubular, tetapi disertai terjadinya piknosis (inti sel menyusut, batas tidak teratur, dan berwarna gelap), serta karioreksis yaitu inti hancur, membentuk fragmen kromatin yang menyebar. Pada kelompok 3 dengan pemajanan 12 jam/hari dan kelompok 4 dengan lama pemajanan 16 jam/hari. Ditemukan pendarahan intra tubular, piknosis, kongesti, kariolisis, karioreksis, dan nekrosis (Gambar 1 -5) 


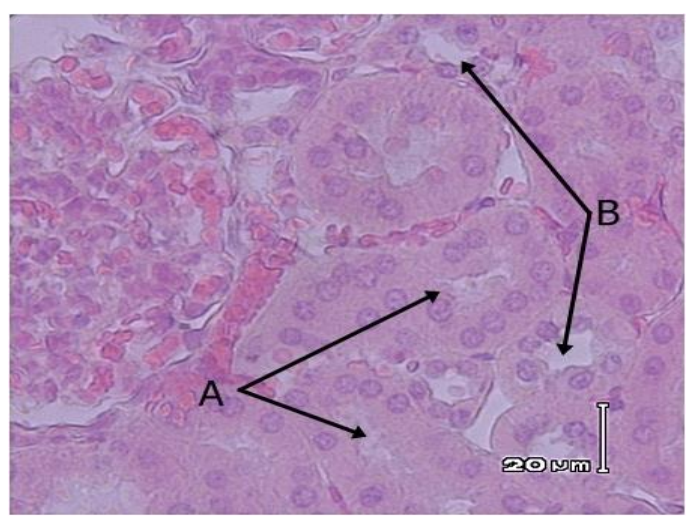

Gambar 1. Struktur histopatologi ginjal mencit jantan yang tidak terpajan lampu merkuri (perbesaran 400x dengan pewarnaan HE). Keterangan A. Tubulus proksimal, B. Tubulus distal

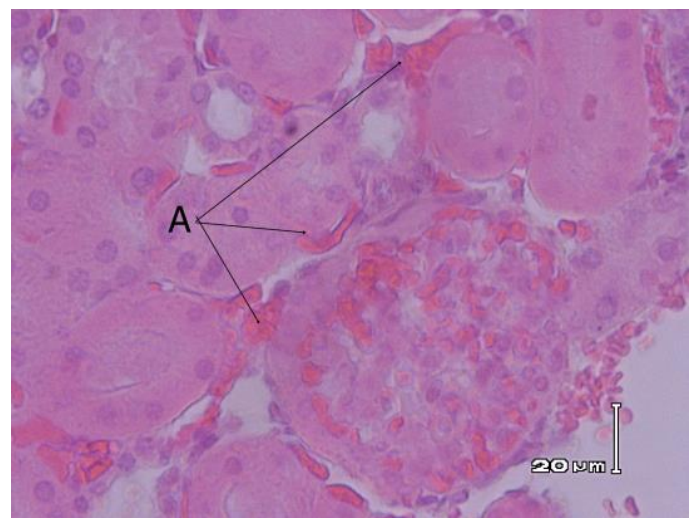

Gambar 2. Struktur histopatologi ginjal mencit jantan yang terpajan lampu merkuri 4 jam/hari selama 21 hari (kanan perbesaran 100x, kiri perbesaran 400x, pewarnaan $\mathrm{HE}$ ). Keterangan : A. Perdarahan intertubular.

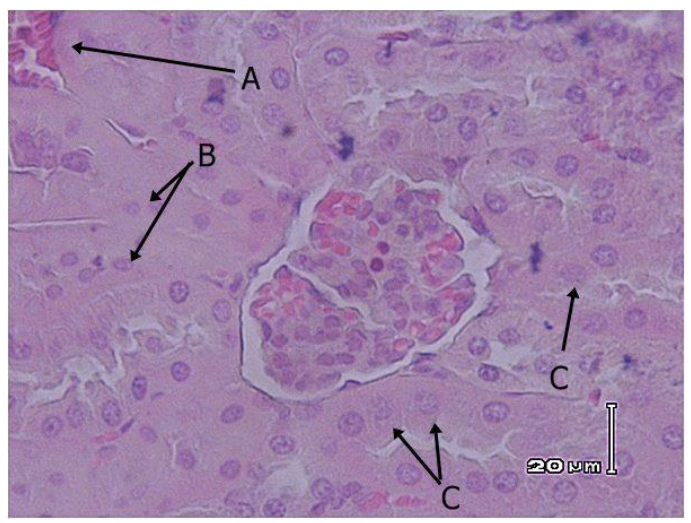

Gambar 3. Struktur histopatologi ginjal mencit jantan yang terpajan lampu merkuri 8 jam/hari selama 21 hari (perbesaran $400 x$, pewarnaan $\mathrm{HE}$ ). Keterangan : A. perdarahan intertubular, B. piknosis, dan C. karioreksis.

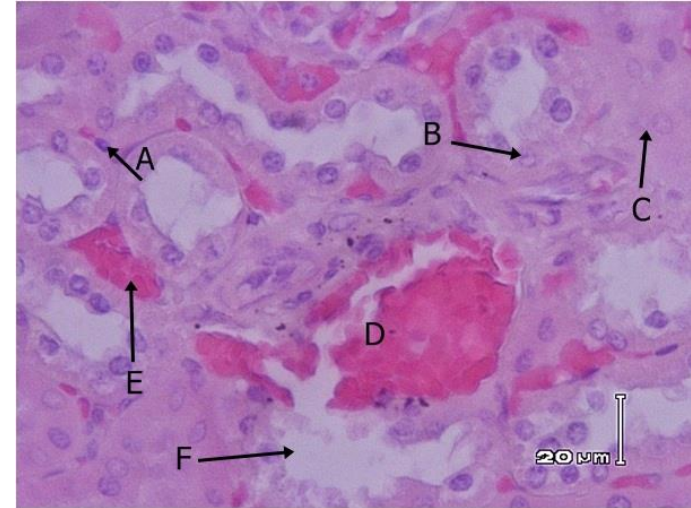

Gambar 4.Struktur histopatologi ginjal mencit jantan yang terpajan lampu merkuri 12 jam/hari selama 21 hari (perbesaran 400x, pewarnaan HE). Keterangan : A. piknosis, B. karioreksis, C. kariolisis, D. kongesti, E. nekrosis dan F. perdarahan intertubular.

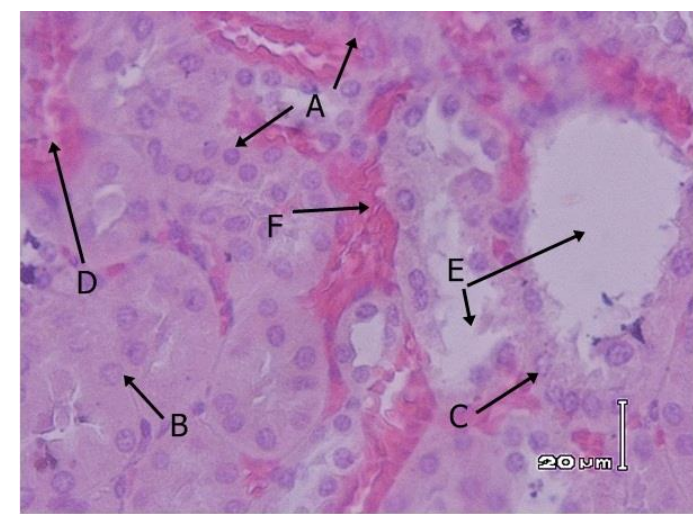

Gambar 5.Struktur histopatologi ginjal mencit jantan yang terpajan lampu merkuri 16 jam/hari selama 21 hari (perbesaran 400x, pewarnaan $\mathrm{HE}$ ). Keterangan : A. piknosis, B. karioreksis, C. kariolisis, D. kongesti, E. nekrosis dan F. perdarahan intertubular.

Radiasi yang dihasilkan oleh cahaya lampu diduga tidak hanya dalam bentuk fisis tampak, tetapi berupa gelombang elektromagnetik yang akan berinterakasi dengan semua materi, khususnya yang bersifat listrik. Pemajanan radiasi cahaya lampu merkuri diduga berinteraksi dengan sel-sel tubuh mencit yang mengandung potensial listrik. Misalnya dalam bidang batas membran sel saraf atau otot terdapat ion-ion yang terdiri dari muatan positif seperti $\mathrm{K}^{+}$dan $\mathrm{Na}^{+}$pada permukaan luar dan ion-ion bermuatan negatif seperti ion $\mathrm{Cl}^{-}$di dalam bidang batas/membran (Cameron, 2006). Induksi yang ditimbulkan oleh gelombang elektromagnetik (EM) yang melebihi batas ambang dapat menyebabkan tersimpannya sejumlah elektron di dalam tubuh. Kondisi ini menyebabkan tubuh mengalami kelebihan elektron, sehingga akan mengganggu sistem saraf dan mengakibatkan koordinasi antar sel terganggu, pada ahirnya kerja organ tubuh akan terganggu (Baffai, 2003). 
Hasil penelitian ini menunjukan bahwa pemajanan yang berbeda pada masing-masing kelompok terhadap gelombang elektromagnetik lampu merkuri menunjukkan variasi kerusakan berbanding lurus dengan lama pemajanan artinya semangkin lama pemajanan semakin banyak kerusakan yang ditemukan. Dari data hasil penelitian pada mencit jantan kelompok 1 (0 jam/hari) yang merupakan kontrol, gambaran histopatologi ginjal tidak menunjukkan adanya kerusakan (Gambar 7). Ditemukan kerusakan berupa perdarahan intertubular pada perlakuan 4, 8, 12, dan 16 jam/hari. Ciri-ciri perdarahan intertubular dapat dilihat pada gambaran histopatologi ginjal dengan ditemukannya darah dalam jumlah banyak di ruang antar tubulus (Gambar 8). Piknosis dan karioreksis ditemukan pada perlakuan 8, 12 dan 16 jam/hari. Selanjutnya kariolisis, kongesti dan nekrosis ditemukan pada perlakuan 12 dan 16 jam/hari (Gambar 10).

Ada dua teori tentang kerusakan sel, baik sel kanker maupun sel normal akibat radiasi elektromagnetik. Yang pertama yaitu teori target, dimana elektron langsung merusak DNA (reaksi langsung) bila radiasi elektromagnetik ini mengenai ginjal hal ini diduga akan menyebabkan inti sel kariolisis, karioreksis dan piknosis. Dan yang kedua teori racun air (reaksi tidak langsung), dimana elektron menimbulkan terbentuknya ion radikal yang dapat rnerusak DNA dan struktur sel lainnya (Yunarti, 2007).

Radiasi elektromagnetik yang mengenai sel diduga menyebabkan atom hidrogen $\left(\mathrm{H}^{+}\right)$pada molekul air mengalami pembelahan heterolitik (ionisasi) sehingga terbentuk ion hidrogen $\left(\mathrm{H}^{+}\right)$ dan ion hidroksil $\left(\mathrm{OH}^{-}\right)$yang sangat reaktif. Radikal hidrogen $\left(\mathrm{H}^{+}\right)$dan hidroksil $\left(\mathrm{OH}^{-}\right)$akan menyebabkan berbagai macam efek pada molekul lain pada sistem biologik sehingga mengganggu integritas sel (Boag, 1975).

Gelombang elektromagnetik juga diduga menyebabkan disorientasi terhadap mencit sehingga menyebabkan sepsis dan syok dimana kejadian ini membuat hipoperfusi ginjal akibat vasodilatasi sistemik dan vasokonstriksi pembuluh darah di ginjal. Hal tersebut akan menginduksi serangkaian lintasan metabolisme yang mengakibatkan pecahnya pembuluh darah di ginjal dapat berupa perdarahan intertubular atau kongesti ginjal (Robbins dan Kumar, 1992).

Dalam penelitian ini nekrosis dapat ditemukan pada perlakuan 12 dan 16 jam/hari (Gambar 10 dan 11). Jelas seperti perdarahan yang berupa kongesti dan perdarahan intertubular yang disebabkan pemajanan gelombang elektromagnetik lampu merkuri diduga menyebabkan ionion seperti natrium dan hidroksil di dalam lumen tubulus meningkat. Peningkatan $\mathrm{Na}^{+}$dan $\mathrm{OH}^{-}$ ini menyebabkan derajad keasaman sel di tubulus meningkat sehingga epitel tubulus terlepas dan mikrovili akan membentuk silinder sehingga terjadi obstruksi tubulus dan ahirnya terjadi nekrosis (Sudoyo et al, 2006).

\section{KESIMPULAN}

Berdasarkan hasil penelitian terhadap struktur histopatologi ginjal mencit jantan yang terpajan lampu merkuri dapat disimpulkan bahwa tubulus ginjal mencit yang terpajan mengalami kerusakan berupa perdarahan intertubular, piknosis, karioreksis, kariolisis, kongesti, dan nekrosis.

\section{DAFTAR PUSTAKA}

Arrington, L. R. 1972. Introductory Laboratory Animal.The Breeding, Care and Management of Experimental Animal Science.The Interstate Printers and Publishing, Inc., New York.

Baffai, U. 2003. Pengaruh Pemaparan Medan Listrik Terhadap Perilaku Mencit. Buletin Utama UISU, V 01.7.

Boag. 1975. The time scale of effect in radiation biology. In : Steel GG. Basic clinical radiobiology. 2nd edition. Oxford university : London

Cameron, R. J. 2006. Fisika Kedokteran: Fisika Tubuh Manusia. Sagung Seto. Jakarta.

Lim, F. 2008. Filsafat teknologi tentang dunia, manusia dan alat. Kanisius : Yogyakarta.

Malole, M. B. M. dan C. SPramono.1989. Penggunaan Hewan-hewan Percobaan Laboratorium. Departemen Pendidikan dan Kebudayaan. Direktorat Jendral Pendidikan Tinggi Pusat Antar Universitas Bioteknologi. Institut Pertanian Bogor : Bogor.

Purnomo, B. 2009. Dasar-dasar Urologi. Sagung Seto: Jakarta.

Robbins, S. L dan Kumar. 1992. Buku Ajar Patologi I. Universitas Airlangga: Jakarta.

Rinawati, W. dan Aulia, D. 2011. Kidney Injury Molecule-1 (KIM-1) sebagai Penanda Baru Nekrosis Tubular Akut. Departemen Patologi Klinik, RSUPN Cipto Mangunkusumo/Fakultas Kedokteran Universitas Indonesia: Jakarta.

Sanchez, O., A. Arnau., M. Pareja., E. Poch., I. Ramirez., J. Araya. 2002. Changes in ( $\mathrm{Na}$ _ K)- Adenosine Triphosphatase Activity and Ultrastuc-ture of Lung and Kidney Associated With Oxidative Stress Induced by Acute Ethanol Intoxication. American College of Chest Physicians. 
Samkhan dan S. Niati. 2006. Tata Cara Penanganan Dan Pengirimam Contoh ke Laboratorium. Buletin Laboratorium Veteriner.. Vol : 6 No:3 http://itp08ub.files.wordpress.com/2012/01/ pedoman-kode-etik-hewan-coba.doc

Siswono, 2008. Teknik listrik industri jilid 1 untuk smk. DEPDIKBUD Dikmenjur : Jakarta.

Sudoyo A.W, Setiyohadi B, Alwi I, K MS, Setiati S. 2006. Buku Ajar IImu Penyakit Dalam. Jakarta: Pusat Penerbitan Departemen IImu Penyakit Dalam FKUI

Valberg, V. A., R. Kavet, and C. N. Rafferty. 1997. Can Low Level 50/60 Hz Electric and Magnetic Field Cause Biological Effects Radiation Research 148, pp2 - 21, 1997.

http://www.scribd.com/doc/37531663/CanLow-Level-50-60-Hz-Electric-andMagnetic-Fields-Cause-Biological-Effects. Diakses 10 juni 2012

Wararindi. 2011. Membuat Preparat Organ. http://wararindi.wordpress.com /2011/06/07/membuat-preparat-organ/. Diakses; Sabtu, 2 Juni 2012.

Yunarti. 2007. Pengaruh Pholiphenols Teh Hijau Terhadap Kapasitas Produksi TNF- $\alpha$ Oleh Sel Mononuklear Darah Tepi Pada Penderita Karsinoma Nasofaring Yang Mendapat Radioterapi. Universitas Diponegoro ; Semarang. Avialable in http://eprints.undip.ac.id/17711/1/Yunarti.p df diakses 30 maret 2013 